Hydraulic Engineering Repository

Ein Service der Bundesanstalt für Wasserbau

Adams, Benjamin; Xiao, Ming Piping Potential of a Fibrous Peat

Verfügbar unter / Available at:

https://hdl.handle.net/20.500.11970/100237

Vorgeschlagene Zitierweise / Suggested citation:

Adams, Benjamin; Xiao, Ming (2010): Piping Potential of a Fibrous Peat. In: Burns, Susan E.; Bhatia, Shobha K.; Avila, Catherine M. C.; Hunt, Beatrice E. (Hg.): Proceedings 5th International Conference on Scour and Erosion (ICSE-5), November 7-10, 2010, San Francisco, USA. Reston, Va.: American Society of Civil Engineers. S. 202-211. 


\title{
Piping Potential of a Fibrous Peat
}

\author{
Benjamin Adams ${ }^{1}$ and Ming Xiao ${ }^{2}$
}

\author{
'Graduate student, Department of Civil and Geomatics Engineering, California State \\ University, Fresno. USA. Email: runinguy@csufresno.edu. \\ ${ }^{2}$ Assistant Professor, Department of Civil and Geomatics Engineering, California State \\ University, Fresno. USA. Email: mxiao@csufresno.edu. Phone: (559) 278-7588.
}

\begin{abstract}
The experimental research presented in this paper aims to develop an understanding of the piping mechanisms of a fibrous peat. The organic matter content of the peat is $22.6 \%$. The peat is compacted to $98 \%$ of its maximum dry density within a $7.0 \mathrm{~cm}$ diameter transparent acrylic cylinder. A hole $0.64 \mathrm{~cm}$ in diameter that penetrates the entire length of the specimen is preformed to simulate an initial piping channel. A constant-head hole-erosion test is performed on the peat specimen. Upon completion of the test, no significantly measurable enlargement of the preformed hole is observed. A comparison is then made with a sandy soil with the same grain size distribution but no organic matter content. The sand is compacted to $100 \%$ of its maximum dry density and tested under the same experimental conditions. Erosion of the piping hole progresses quickly toward the perimeter of the mold. To better understand the effect that organic matter may have on erosion resistance, the sand and the peat are mixed to create a composite soil exhibiting similar soil properties. The newly constituted soil is compacted to its maximum dry density and tested under the same experimental conditions. Only a slight increase in the hole size is observed after the test. The preliminary study suggests that (1) the presence of organic matter in soils may cause initial piping erosion rates to decrease toward a stable value; (2) organic matter content appears to play a role in a soil's resistance to piping progression; the presence of a small percentage of organic matter results in a drastic increase in a soils ability to resist this form of erosion.
\end{abstract}

\section{INTRODUCTION}

Internal erosion in soil can severely weaken dams, dikes, and levees, and can lead to eventual failure and breaching of these hydraulic earth structures. While the mechanisms contributing to internal erosion in mineral soils are still not fully understood, an even less known process is that of internal erosion in organic soils such as peat. Peat is prevalent, with deposits being found in many parts of the world, including 42 states within the United States (Mesri and Ajlouni, 2007). The intention of this research is to provide a preliminary understanding of the mechanisms involved in internal erosion in peat, and the potential for internal erosion that peat possesses. This information could aid in risk analysis and design procedures of hydraulic earth structures. 
In recent years, many researchers have continued to study subsurface soil erosion of various combinations of gravel-sand-silt-clay mixtures and the effects of various soil properties on the erosion process. One form of internal erosion is referred to as piping. This type of erosion occurs when concentrated seepage, either through cracks formed due to differential settlement or poor compaction around conduits, or through zones of high permeability within the soil mass, reaches an exit point and carries away both fine and coarse soil particles. This erosion progressively advances upstream along the path of seepage, forming a hollow tube-like channel within the soil mass. This creates the potential for increased seepage and erosion within the hollow pipe and eventual disintegration of the earth embankment or collapse of the open flow tunnel and the structure itself. In a survey of 11,192 dams, Foster et al. (2000) concluded that approximately $46 \%$ of all dam failures could be attributed to internal erosion. In reanalyzing this survey, Richards and Reddy (2008) determined that approximately $31 \%$ of dam failures resulted from the piping mode of failure. Figure 1 shows the Upper Jones Tract levee failure, which took place on June 4, 2004 near Stockton, California. The failure occurred on a sunny morning on which no seismic activity was recorded in the area. Although the exact cause of the incident was never determined, it is speculated that internal piping channels and a high water level led to the failure. After construction of a pumping system, five months were required to dewater the flooded farmland that had been protected by the levee, and the entire cost of the repair came to $\$ 90$ million.

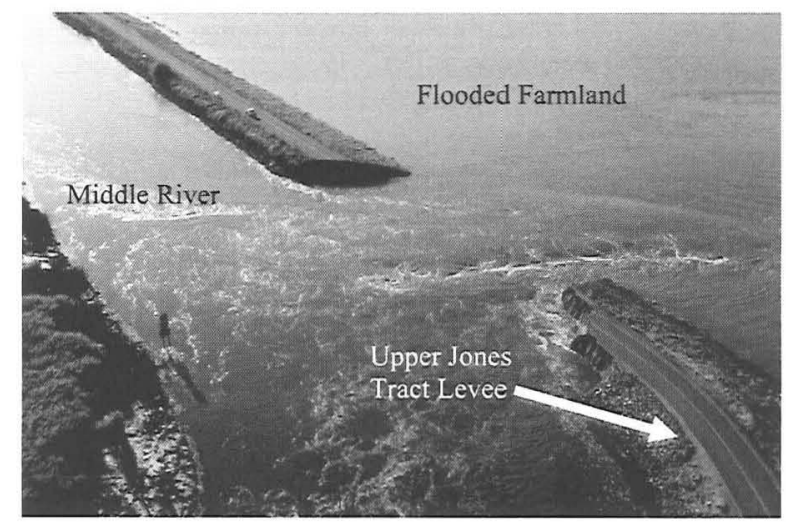

Figure 1. Upper Jones Tract levee breach; June 4, 2004 (DWR, 2004)

The susceptibility to internal erosion of levees built on or near peat deposits is currently unknown. Peat has always been considered an unsuitable building material due to its high compressibility, and its engineering properties have been relatively unstudied. This highly organic soil can attribute its organic content to the decomposition of fragmented plant and animal remains that can accumulate in lush, 
vegetative environments. Although the same fundamental principles that govern inorganic mineral soil behavior may be applicable to organic peats, the basic engineering properties of peat are significantly different from those of mineral soils (Mesri and Ajlouni, 2007). After a comprehensive review of previous research on peat soils, in conjunction with their own research on two types of peat, Mesri and Ajlouni (2007) pointed out the extremely high in situ permeability and void ratios that are typically exhibited by peat. Another typical characteristic of peat, resulting from its high in situ void ratio coupled with the high water holding capacity of the organic material, is its high compressibility under overburden stress. Peats usually have low specific gravity. The combination of low density, high void ratio, and high permeability seems to suggest that peat might be susceptible to internal erosion.

Due to the potentially complex interaction of the mechanisms possibly involved in internal erosion, i.e. grain size distribution, compaction, hydraulic gradient, cohesion, internal friction angle, and organic content, a systematic study is necessary in order to understand the effects that each of these parameters might play in a soils internal erosion potential. In this paper, we present our preliminary findings on the internal erosion potential of peat and its comparison with that of a mineral soil.

\section{TEST MATERIALS AND SOIL CHARACTERIZATION}

Three types of soils are studied in order to examine the various soil characteristics possibly affecting internal erosion potential in peat. The basic characteristics of each soil are shown in Table 1.

Table 1. Basic Soil Properties

\begin{tabular}{|c|c|c|c|}
\hline Soil Property & Kerman Peat & $\begin{array}{r}\text { Fine Grained } \\
\text { Sand }\end{array}$ & Composite \\
\hline Organic matter content $(\%)$ & 22.6 & 0.0 & 5.0 \\
\hline $\begin{array}{l}\text { Maximum dry density }\left(\mathrm{g} / \mathrm{cm}^{3}\right) \text {; } \\
\text { optimum moisture content }(\%) \\
\text { (Harvard Miniature compaction) }\end{array}$ & $\begin{array}{r}0.94 \\
46.0\end{array}$ & $\begin{array}{r}1.94 ; \\
9.5\end{array}$ & $\begin{array}{l}1.59 ; \\
16.0\end{array}$ \\
\hline Cohesion (drained direct shear) & $\begin{array}{r}27.3 \mathrm{kN} / \mathrm{m}^{2} \\
\text { (or } 4.0 \mathrm{lb} / \mathrm{in}^{2} \text { ) }\end{array}$ & $\begin{array}{r}22.0 \mathrm{kN} / \mathrm{m}^{2} \\
\text { (or } 3.2 \mathrm{lb} / \mathrm{in}^{2} \text { ) }\end{array}$ & $\begin{array}{r}10.6 \mathrm{kN} / \mathrm{m}^{2} \\
\text { (or } 1.5 \mathrm{lb} / \mathrm{in}^{2} \text { ) }\end{array}$ \\
\hline $\begin{array}{l}\text { Internal friction angle }\left(^{\circ}\right) \\
\text { (drained direct shear) }\end{array}$ & 32.9 & 38.8 & 41.3 \\
\hline
\end{tabular}

The soil here referred to as Kerman Peat is light in color, contains visible organic fibers and large soil particles, and is non-plastic. It was sampled from a dry riverbed in Kerman, CA. The peat was sampled and immediately placed in airtight containers at room temperature $\left(20-22^{\circ} \mathrm{C}\right)$ for storage and testing. The grain size distribution (GSD) of the peat (from wet sieving and hydrometer analysis) is shown in Fig 2. The mineral soil here referred to as Fine Grained Sand was created by deliberately manipulating the grain size distribution of a fine-grained sandy soil intended for use in urban construction. The sand was separated into the portions 
retained on sieves of selected sizes, and the grain size distribution of the peat was used to develop the mixing ratio necessary to achieve a sandy soil with the same gradation. Figure 2 shows the similarity in grain size distribution between the peat and the sand. Note that the portion of the sand passing the No. 200 sieve $(0.075 \mathrm{~mm})$ is an average of the slightly varying results obtained from multiple hydrometer tests on the Kerman Peat.

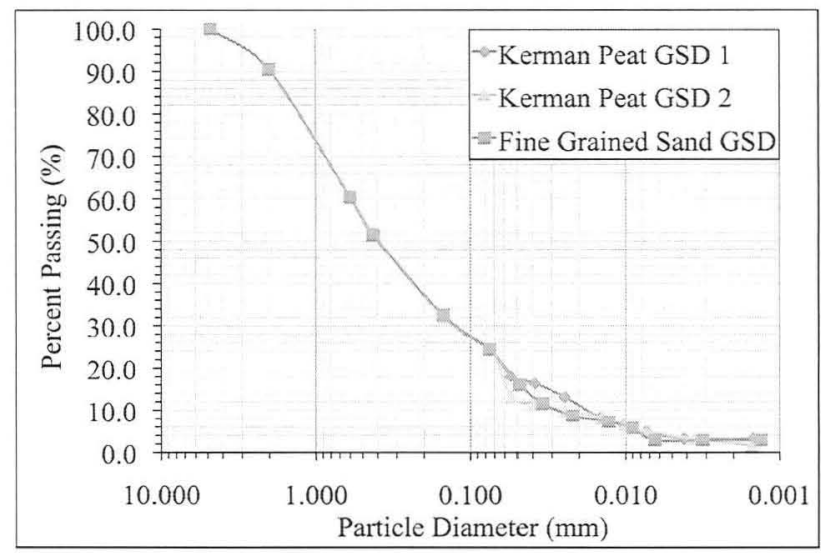

Figure 2. Grain size distributions of Kerman Peat and Fine Grained Sand

The third soil, here referred to as the composite soil, was also created in the laboratory and was a mixture of the sand and the peat. The two soils were mixed at a mass ratio of $22 \%$ peat to $78 \%$ sand, creating a sandy soil having $5 \%$ organic content by mass. Since the two soils with the same grain size distribution were the only components used in creating this composite soil, the mixture exhibits basic soil properties similar to those of its constituents. The purpose of creating the mineral soil (with $0 \%$ organic matter content) and the composite soil (with $5 \%$ organic matter content) is to examine the possible effect of organic matter content on internal erosion resistance.

In order to study the effect of cohesion and internal friction angle on the soils' internal erosion, drained direct shear tests are conducted on the peat, the sand, and the composite soil, which are compacted at their optimum moisture content and at compaction ratios of $98 \%, 100 \%$, and $100 \%$, respectively. The results are shown in Table 1. 


\section{EXPERIMENTAL METHODOLOGY}

To conduct the erosion tests, the improvised hole-erosion test (HET) apparatus shown in Figure 3 has been developed. The device is modeled after the apparatus developed by the researchers at the University of New South Wales (Wan and Fell, 2004a; 2004b). The test is conducted on specimens measuring $7.0 \mathrm{~cm}$ in diameter and $13.5 \mathrm{~cm}$ in length. Clear acrylic tubing and end caps, which allow for easy observation of the specimen during all phases of testing, are used for the specimen mold. The end caps are designed in such a way that eroded soil particles are able to exit from the specimen unhindered. The hole diameter of the influent end cap is drilled to the same size as that of the simulated piping channel allowing for direct introduction of eroding fluid into the channel. This straight hole measuring $0.64 \mathrm{~cm}$ in diameter is preformed during the specimen compaction using a metal rod. The soil specimen is compacted directly within the mold in thin, uniform layers at optimum moisture content. De-ionized water is introduced via a constant head reservoir, and the effluent with eroded soil particles is collected in buckets directly beneath the specimen. With the downstream side of the specimen open to atmosphere, a constant hydraulic gradient of four is established for conducting the erosion tests, simulating possible field conditions.

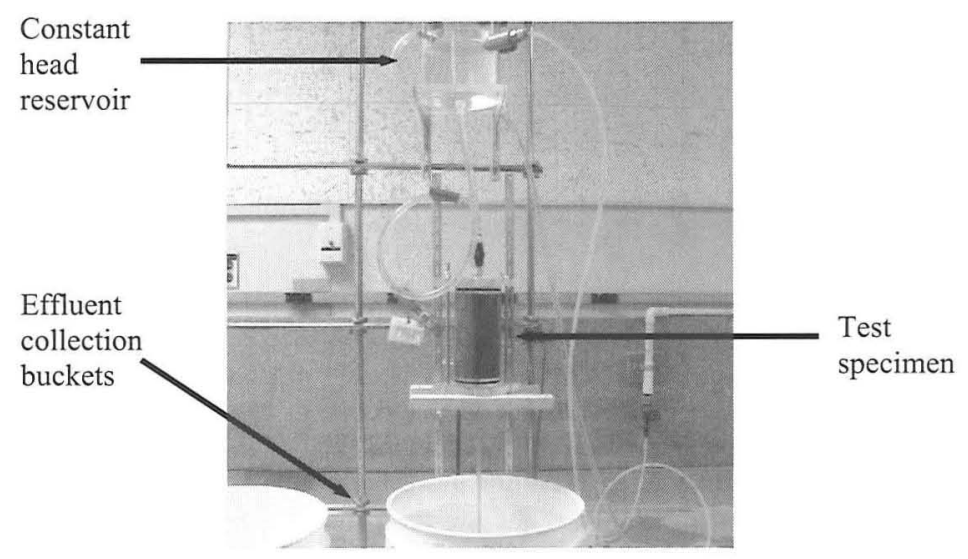

Figure 3. HET apparatus and test specimen

Throughout the duration of each test, effluent is collected for predetermined incremental lengths of time. Based on the mass of water collected during each increment, the corresponding effluent volume can be calculated. Also determined in each time increment is the total dry mass of eroded soil. This mass is obtained through decanting and drying of the effluent with eroded particles. Then, average seepage and erosion rates for each increment of time can be determined. Table 2 summarizes the test conditions for each soil type. 
Table 2. Erosion Test Parameters

\begin{tabular}{|l|r|r|r|}
\hline \hline Test Parameter & Kerman Peat & $\begin{array}{r}\text { Fine Grained } \\
\text { Sand }\end{array}$ & Composite \\
\hline Duration of test (min) & 60 & 3 & 60 \\
\hline Duration of each increment (min) & 5.0 & 0.5 & 5.0 \\
\hline Hydraulic gradient & 4 & 4 & 4 \\
\hline Compaction ratio (\%) & 98 & 103 & 100 \\
\hline \hline
\end{tabular}

\section{RESULTS AND DISCUSSION}

At the end of each erosion test, the condition of the piping hole is recorded. As shown in Figure 4(a), no measurable difference is observed in the preformed piping hole after the peat specimen experiences a full hour of eroding flows. Figure 4(b) shows that after experiencing only three minutes of the same flow conditions, the initial hole in the sand specimen has eroded to the perimeter of the mold. The soil and test parameters (grain size distribution, cohesion, internal friction angle, and compaction ratio) are similar in both specimens. However, a drastic variation in the erosion potential is observed between the two soils. The composite soil specimen, also having similar soil parameters but differing in organic content, is shown in Figure 4(c). This soil is also tested for a duration of 60 minutes and shows an intermediary level of piping hole enlargement and soil erosion, which is only slightly greater than that of the peat specimen. A summary of the test results is presented in Table 3.

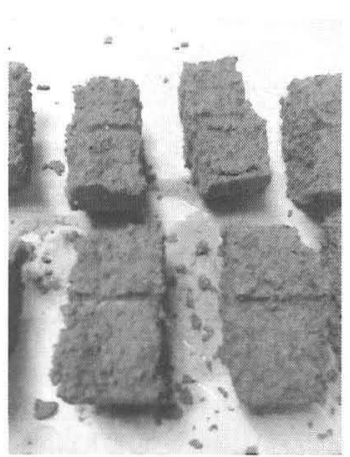

(a) Peat specimen

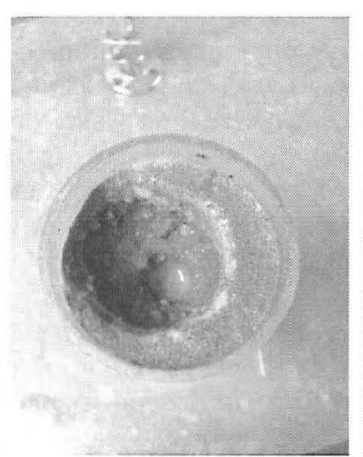

(b) Sand specimen

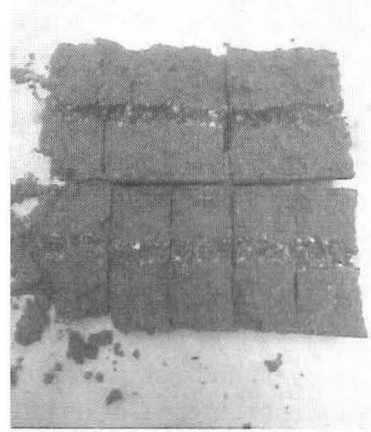

(c) Composite specimen

Figure 4. Post-erosion condition of test specimens with piping holes 
Table 3. Erosion Test Results Summary

\begin{tabular}{|l|r|r|r|}
\hline Test Results & Kerman Peat & $\begin{array}{r}\text { Fine Grained } \\
\text { Sand }\end{array}$ & $\begin{array}{r}\text { Composite } \\
\text { Soil }\end{array}$ \\
\hline Maximum erosion rate (g/min) & 0.12 & 38.80 & 0.94 \\
\hline $\begin{array}{l}\text { Average erosion rate during all } \\
\text { increments (g/min) }\end{array}$ & 0.03 & 24.00 & 0.13 \\
\hline Hole condition at the end of test & $\begin{array}{r}\text { No visible } \\
\text { change } \\
\text { [Fig. 4(a)] }\end{array}$ & $\begin{array}{r}\text { Considerable } \\
\text { erosion } \\
\text { [Fig. 4(b)] }\end{array}$ & $\begin{array}{r}\text { Slight } \\
\text { enlargement } \\
\text { [Fig. 4(c)] }\end{array}$ \\
\hline
\end{tabular}

Figure 5 shows the variation of average erosion and seepage rate with time during each test. Each point represents the average erosion or seepage rate for the duration of that particular time increment. The initial point of each test in Figure 5(a) may not be reliable - during the formation of the piping channel at specimen compaction, the removal of the metal rod used to form the piping hole can cause soil particles to dislodge from the wall of the hole. The assembly of the cylinder and the end caps can also cause a slight disturbance of the specimen. These loose particles are easily washed from the specimen upon the initiation of the test (due to water hammer) and are collected in the first effluent bucket, causing the eroded soil mass to be unrealistically high. This is supported by the fact that for each soil type, the first point is significantly higher than subsequent points. This possible procedural error also affects the reported maximum and average erosion rates.

Figure 5(a) shows that the erosion rates of both the peat and the composite soil follow a decreasing trend toward a stabilizing value, while the sand erosion rate appears to be increasing at the end of the test. The generally increasing and then stabilizing seepage rates observed in the peat and the composite soil tests, as shown in Figure 5(b), also indicate the progression of the piping channel. As the piping hole enlarges due to initial erosion, the seepage rate increases. Once the erosion rate has decreased, the hole size stabilizes and the seepage rate through the hole also stabilizes. Due to the high erosion potential of the sand and the subsequently low number of data points for this test, a clear trend is more difficult to distinguish. Most important to recognize, however, is the high erosion potential of this non-organic soil.

These results indicate the possible effect of organic matter content on a soil's erosion resistance - soils with higher organic matter content erode less under the same soil compaction and hydraulic conditions. Soil organic matter has been shown to affect erosion resistance. Organic matter binds mineral particles into a granular soil structure; part of the soil organic matter that is especially effective in stabilizing these granules consists of certain glue-like substances produced by various soil organisms (Brady and Weil, 2002; Haynes and Beare, 1996). Application of compost in surface erosion control employs this principle. Mazurak et al. (1975) reported that application of organic wastes decreased the amount of soil particles detached by raindrop impact. Xiao and Gomez (2009) also found that surface erosion resistance of composts increases with the increase of organic matter content. It seems 
the surface erosion mechanisms could be extended to the internal piping erosion. Closer examination of the post-erosion piping hole of the composite soil [Figure 4(c)] shows larger granular sand particles (in lighter color) remained on the wall of the hole, indicating the "binding" of organic particles with the mineral particle, preventing them from eroding.

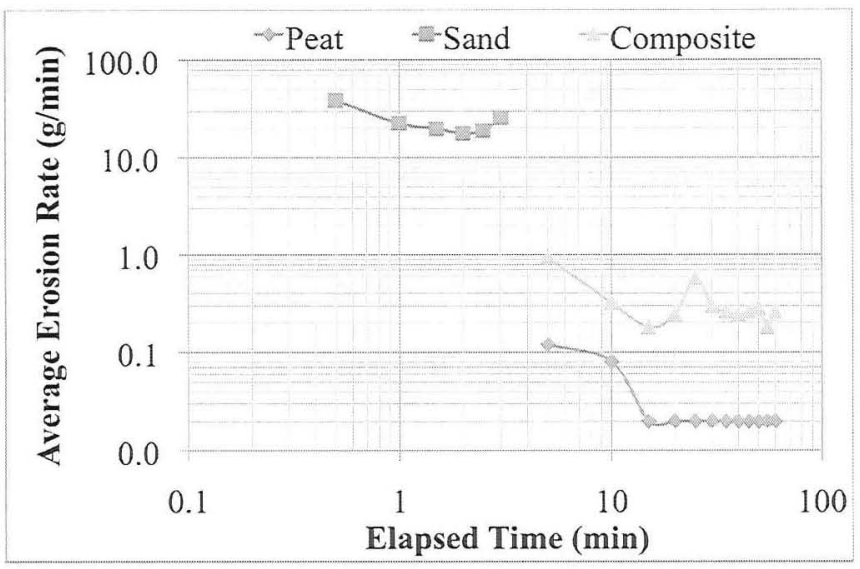

(a) Erosion rate with time

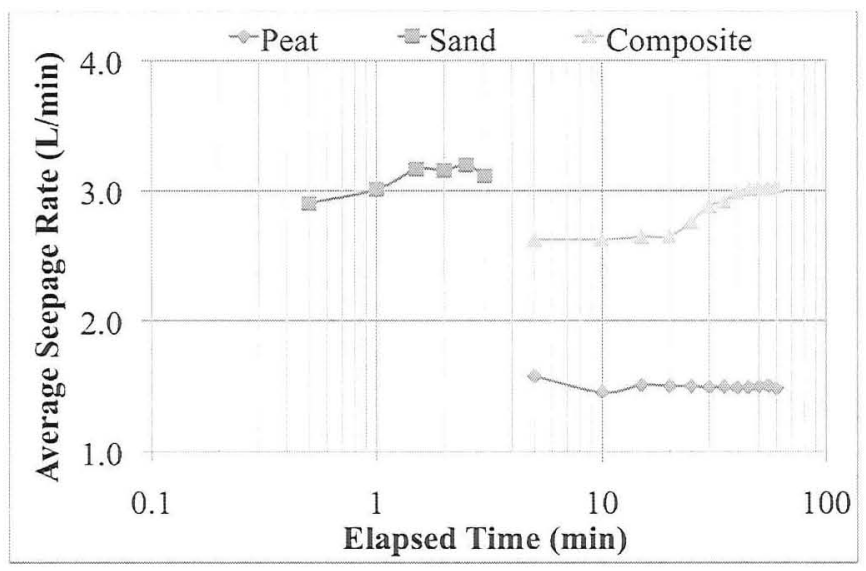

(b) Seepage rate with time

Figure 5. Average erosion rate and seepage rate based on HET results for the three tested soils 
Shear strength parameters were analyzed within the context of piping erosion. It appears that inter-particle friction may not play a significant role in piping erosion resistance given that soil solids at the soil-water interface along the open channel are subjected to nominal effective stress; therefore, internal friction angles of the three types of soil (Table 1), albeit different, may not be attributed to the erosion difference. The impact of cohesion on erosion resistance is inconclusive, based on the results shown in Figure 5(a). The composite soil with lower cohesion of 10.6 $\mathrm{kN} / \mathrm{m}^{2}$ but higher organic matter content $(5 \%)$ has significantly higher erosion resistance than that of sand, whose cohesion is higher $\left(22.0 \mathrm{kN} / \mathrm{m}^{2}\right)$ but organic matter content is less $(0 \%)$.

The study reported in this paper did not consider the effects of particle shape and structure on the erosion process. Although the three soil types have the same grain size distribution, the individual particle shapes are quite different - sand solids are either round or angular in shape, while the peat particles are mostly flakes. Moreover, Mesri and Ajlouni (2007) demonstrated that fibrous peat particles have a hollow, perforated cellular structure. The authors are conducting further study to understand the relationships between organic content, particle shape and size, and resistance to piping erosion.

\section{CONCLUSIONS}

This paper presents the findings of a preliminary study of the mechanisms involved in piping erosion and the role that organic matter content may play in resisting piping progression. Hole erosion tests were carried out on three soils having varied organic matter contents but the same grain size distribution using an improvised hole erosion test apparatus. The research presented in this paper suggests the following conclusions:

1. The presence of organic matter in soils may cause initial piping erosion rates to decrease toward a stable value.

2. Organic matter content appears to play a role in a soil's resistance to piping progression. The presence of a small percentage of organic matter, i.e., 5\%, results in a drastic increase in a soils ability to resist this form of erosion.

\section{REFERENCES}

Brady, N.C., and Weil, R.R. (2002). The Nature and Properties of Soils, 13th edition. Prentice Hall.

California Department of Water Resources (DWR) (2004, June). "Photographs of the Upper Jones Tract Levee Break in the Sacramento-San Joaquin Delta."

Retrieved December 16, 2009, from www.water.ca.gov/news/newsreleases/2004/061604floodpic.pdf

Foster, M., Fell, R., and Spannagle, M. (2000). "The Statistics of Embankment Dam Failures and Accidents." Canadian Geotechnical Journal, 37(5): 1000-1024. 
Haynes, R.L., and Beare, M.H. (1996). "Aggregation and organic matter storage in meso-thermal, humid soils." Structure and organic matter in agricultural soils. Advances in Soil Science, ed. M.R. Carter and B.A. Stewart, 213-263. Boca Raton, FL: Lewis-CRC Press.

Mazurak, A.P., Chesnin, L., and Tiarke., A.E. (1975). "Detachment of soil aggregates by simulated rainfall from heavily manured soils in eastern Nebraska." Soil Science Society of America Journal, 39:732-736.

Mesri, G., and Ajlouni, M. (2007). "Engineering properties of fibrous peats." Journal of Geotechnical and Geoenvironmental Engineering, 133 (7): 850-866.

Richards, Kevin S. \& Reddy, K.R. (2008). "Experimental Investigation of Piping Potential in Earthen Structures" Geotechnical Special Publication \#178, GeoCongress 2008: Geosustainability and Geohazard Mitigation, pp. 367-376

Wan, C. F., and Fell, R. (2004a). "Investigation of Rate of Erosion of Soils in Embankment Dams" Journal of Geotechnical and Geoenvironmental Engineering, 130 (4): 373-380.

Wan, C. F., and Fell, R. (2004b). "Laboratory Tests on the Rate of Piping Erosion of Soils in Embankment Dams" Geotechnical Testing Journal, 27 (3): 295-303. ASTM International, West Conshohocken, PA, DOI: 10.1520/GTJ11903.

Xiao, M. and Gomez, J. (2009). "Rainfall erosion resistance and stability of various composts." Journal of Soil and Water Conservation, 64(4): 233-242. 